\title{
Food-and-wine experiences towards co-creation in tourism
}

Susana Andreia Salgueiro Rachão, Zelia Breda, Carlos Fernandes and Veronique Joukes

\begin{abstract}
Purpose - In general, literature recognises that co-creative experiences add value to the tourism experience, yet empirical research within food-and-wine context remains scarce. This study aims to analyse the tourists' perceptions of the co-creation construct, their food-and-wine tourism experiences and their willingness to actively co-create in this type of experiences.

Design/methodology/approach - Departing from general co-creation theoretical concepts, this research explores how they can be applied in a specific food-and-tourism context. The end goal is to formulate a model that can be applied by food-and-wine managers when they create their tourism experience. A convenience sample of 19 tourists composed by 1 focus group (5 participants) and 14 face-to-face semi-structured interviews provided data for the qualitative research to explore tourists' perceptions of co-creation and how these perceptions can be used to create engaging and successful food-and-wine experiences.
\end{abstract}

Findings - Results reveal that co-creation is perceived by tourists as one or a combination of seven categories: social interaction, novelty, creativity, social sustainability, environmental awareness, enjoyment and memorable experiences. Respondents have participated in food-and-wine activities while travelling as a complement to their tourism experience displaying more willingness to actively participate in food rather than wine experiences.

Research limitations/implications - This study is exploratory in nature which makes the data not generalisable. The findings need further quantitative validation. Although the food-and-wine experiences were created based on existing experiences, they are composed of a different number of stages (without standardisation), which may make further statistical analysis (comparisons) difficult.

Practical implications - By conceptualising the co-creation construct, tourism managers may use the outcome of this study to turn their experiences more environmentally friendly and to improve the creative process of the experiences. The research findings not only emphasise the significance of understanding tourists' co-creation conceptualisation, but also indicate the importance of integrating creativity and environmental awareness dimensions into experiences. Particularly, the study develops a theoretical model supportive of the co-creation dimensions that can be applied on food-and-wine tourism contexts.

Originality/value - This study fills a gap in the literature between co-creation in tourism and its application in food-and-wine settings by highlighting the significance that co-creation has in developing tourism business experiences.

Keywords Co-creation, Food-and-wine experiences, Tourism, Demand perspective, Content analysis Paper type Research paper

“美食十红酒”式体验实现旅游共创

目的 : 总体而言, 历史文献表明共创可以增加旅游业的价值, 然而, 以美食和红酒为㸴究背景的实证研究还 很少。该探索性砶究旨在分析游客对共同创造结构的看法、游客的“美食十红酒”式旅游体验以及他们在 这种类型的体验中积极共创的意愿。

㸴究设计 : 基于共创理论概念, 该㸴究探讨如何将共创理论运用到具体的“美食+红酒“模式背景中, 该研究 的最终目的是为美食和红酒领域的管理者提供一套模型, 用于开发旅游体验。该文章采用质化分析方式, 针对19名游客, 采用焦点小组 (5个参与者) 与面对面、牛结构式采访 (共14个) 的方式收集数据, 从而 探索游客对共创的理解以及如何结合这些看法开发富有吸引力且成功的“美食+红酒”旅游体验。

㸴究结果 : 砶究结果表示, 游客认为共创由以下七大要素组合而成: 社交互动、新颖性、创造力、社会可 持续性、环保意识、享受和难忘的经历。为丰富旅游经历, 受访者在旅行途中参与了"美食十红酒'活动, 他们表示相比较红酒类的体验, 更愿意积极参加和美食相关的活动。此外, 该研究揭示了开发环保类体验 的重要性。
Susana Andreia Salgueiro Rachão is based at the Department of Economics, Management and Industrial Engineering, Universidade de Aveiro, Aveiro, Portugal, and Department of Economics, Sociology and Management,

Universidade de Tras-osMontes e Alto Douro, Vila Real, Portugal. Zelia Breda is based at the Department of Economics,

Management, Industrial Engineering and Tourism, Universidade de Aveiro, Aveiro, Portugal. Carlos Fernandes is based at the School of Technology and Management, Polytechnic Institute of Viana do Castelo, Viana do castelo, Portugal.

Veronique Joukes is based at the Department of Economics, Sociology and Management, University of Trás-os-Montes and Alto Douro, Vila Real, Portugal.

Received 25 January 2019 Revised 6 May 2019 21 July 2019

12 September 2019 21 October 2019 Accepted 24 October 2019 
㸴究局限: 该㸴究从本质上来说是一次探索性的㸴究, 其数据不具普遍概括性。㸴究结果还需进一步的定 量验证。尽管”美食+红酒”体验是基于现有体验而创造开发出来的, 但它们由一系列不同的步骤构成（没 有标准化），这使得未来的数据对比分析更加艰难。

实际意义：通过概念化共创的构架, 旅游管理者可以利用该研究的研究成果使旅游体验更具环保性, 同时 可以优化体验的创造过程。

理论意义: 该研究成果不仅强调了解游客共创概念的重要性, 而且表明将创造力和环保意识融合到旅游体 验中的重要性。特别是, 该研究开发了支持共创维度的理论模型, 该模型可用于“美食+红酒”旅游模式。

硏究独创性/价值: 该㸴究通过强调共创在发展旅游业务体验过程中的重要性, 填补了旅游共创及其在“美 食+红酒'模式中的应用之间的研究空白。

关键词: 关键词共创, “美食十红酒, ”体验, 旅游, 需求观点, 内容分析

文章类型 : 硎究论文

\section{La experiencia gastronómica y enológica: hacia la co-creación en turismo}

Objetivo : En general, la literatura reconoce que las experiencias co-creativas añaden valor a la experiencia turística, pero la investigación empirica dentro del contexto gastronómico y enológico sigue siendo escasa. El presente estudio exploratorio pretende analizar la percepción de los turistas sobre la construcción de la co-creación, sus experiencias en turismo gastronómico y enológico y su voluntad de co-crear activamente en este tipo de experiencias.

Diseño/metodología/enfoque : Partiendo de los conceptos teóricos generales sobre co-creación, esta investigación explora cómo pueden aplicarse al contexto especifico de la gastronomía y el turismo. El objetivo final es formular un modelo que puedan aplicar los gestores gastronómicos y enológicos cuando creen su experiencia turística. Una muestra de conveniencia de 19 turistas compuesta por un grupo focal (cinco participantes) y catorce entrevistas semiestructuradas en persona, proporcionaron los datos para la investigación cualitativa con el fin de explorar las percepciones de co-creación de los turistas y cómo se pueden emplear para crear experiencias gastronómicas y enológicas atractivas y exitosas.

Resultados : Los resultados revelan que la co-creación es percibida por los turistas como una o una combinación de siete categorias: interacción social, novedad, creatividad, sostenibilidad social, conciencia ambiental, disfrute y experiencias memorables. Los encuestados han participado en actividades relacionadas con la gastronomía y la enología mientras viajaban, como complemento a su experiencia turística, mostrando una mayor disposición a participar activamente en las experiencias gastronómicas que en las enológicas.

Limitaciones del estudio/implicaciones: Este estudio es de carácter exploratorio lo que hace que los datos no sean generalizables. Los resultados necesitan una mayor validación cuantitativa. Aunque las experiencias gastronómicas y enológicas se crearon a partir de experiencias existentes, se componen de un número diferente de etapas (sin normalización), lo que puede dificultar el análisis estadístico posterior (comparaciones).

Implicaciones prácticas : Implicaciones prácticas: Al conceptualizar el concepto de co-creación, los gestores turísticos pueden utilizar el resultado de este estudio para convertir sus experiencias en más respetuosas con el medio ambiente y para mejorar el proceso creativo de las mismas.

Implicaciones teóricas: : Los resultados de la investigación no sólo subrayan la importancia de entender la conceptualización de la co-creación de los turistas, sino que también indican la importancia de integrar la creatividad y la conciencia medioambiental en sus experiencias. En particular, el estudio desarrolla un modelo teórico que apoya las dimensiones de la co-creación que pueden aplicarse en el contexto del turismo gastronómico y enológico.

Originalidad/interés : Este estudio llena el vacío existente en la literatura sobre la co-creación en turismo y su aplicación a entornos gastronómicos y enológicos, destacando la importancia de la cocreación en el desarrollo de experiencias en los negocios turísticos.

Palabras clave : co-creación, Experiencias gastronómicas, Turismo, Perspectiva de demanda, Análisis de contenido

Tipo de papel : Trabajo de investigación

\section{Introduction}

Experience seekers are moving away from standardisation and purely material goods and are looking for "authenticity" in the places they visit and select customised travel. These more "authentic" experiences are related to the gastronomic heritage of destinations, taking many forms and provoking interactions among tourists and with the visited destination 
(Hall et al., 2003; Long, 1998; OECD, 2012; UNWTO, 2017). As a result, tourism experiences combining food/drink and culture have a growing central role in themed museums and exhibitions (Garibaldi and Pozzi, 2018). Tourists are getting involved with destinations by tasting local food and wines, and as a result they collect higher memorabilia in each place visited, because of its uniqueness and authenticity (Williams et al., 2019). This involvement in food-and-wine experiences is reflected by an increase in learning experiences, such as cooking classes or wine-making workshops (Paulauskaite et al., 2017; Stone et al., 2017). However, academics attest a gap in understanding the tourists' willingness to adhere to co-creation experiences based on active participation and interaction indicators (Campos et al., 2018). Further, the assessment of the level of cocreation in tourism experiences' research is needed (Hwang and Seo, 2016).

Despite the increasing literature regarding tourist food and beverages consumption (Alonso and Yi, 2010; Alonso et al., 2015; Bruwer, 2003; Bruwer et al., 2018; Charters et al., 2009; Charters and Menival, 2011), few research studies have comprehensively explored the elements affecting tourists' active participation in food-and-wine experiences. The research about connecting food experiences and co-creation is also limited (Chen, 2018). Only recently, steps in this direction have been taken; Chen (2018) highlighted the unique atmosphere co-created between customers and suppliers in typical Hong Kong teahouses; Chien et al. (2018) focused on the interactivity in food-tourism experiences for the enhancement of a recommendation intention, while Williams et al. (2019) concentrated on the memorability of food experiences through learning about and active participation in the preparation of regional dishes.

This study aims to fill a gap of knowledge on co-creation from a tourism demand-side perspective by, firstly, analysing the tourists' perceptions of co-creation and subsequently using these perceptions for the creation of food-and-wine tourism experiences. Specifically, it intends to theoretically contextualise the co-creation construct in the tourism industry to conceptualise a new model for tourism professionals. By exploring tourists' perceptions on co-creation and by analysing their willingness to actively participate in food-and-wine activities, a model for the co-creation of food-and-wine tourism experiences is proposed.

\section{Literature review}

\section{The co-creation construct in tourism experiences}

Experiences can "touch" people better than products or services (Binkhorst and Den Dekker, 2009). However, they are intangible, subjective and personal (Morgan, 2007; O'dell, 2007), which make their conceptualisation and operationalisation a challenge. Experiences are the dynamic and core elements of the tourism industry (Kim et al., 2012; Neuhofer et al., 2014; Mathis et al., 2016). They are seen as a dynamic phenomenon that is changing, depending on the emotional attributes of the individual connected to his affective psychological processes (Zatori and Beardsley, 2017; Campos et al., 2018). They also result from the interaction between destinations and tourists (Stamboulis and Skayannis, 2003), which leads to co-creation practices in tourism.

The co-creation construct, firstly developed in a context of storytelling experiences, is used to improve the involvement of tourists with tourism businesses (Mossberg, 2008). It is further theorised by Binkhorst and Den Dekker (2009) who place the consumer as a crucial resource to add value to tourism. Tourists and local residents (hosts) can co-create, when they share and enjoy everyday life (Paulauskaite et al., 2017) and when both parties are willing to invest in social interactions (Ngamsirijit, 2014). These social interactions are the essence of co-creation processes and an important factor in the value construct (Bertella, 2015; Bertella et al., 2018; Reichenberger, 2017; Schuckert et al., 2018;Tung et al., 2017). Some studies are continuously emphasising the importance of other travellers in co-creating experiences based on the customer-dominant logic approach (Rihova et al., 2015; 
Rihova et al., 2019), echoing the positive affective, social, functional and network value outcomes (Rihova et al., 2018).

Numerous authors underline the opportunities that information and communication technologies (ICTs) offer to destination managers to co-create tourism experiences (Michael et al., 2009; Neuhofer et al., 2012, 2014). Also, ICTs are seen as supporters in the development of innovative tourism products (Eide et al., 2017).

Under a heritage/cultural spaces focus, co-creation processes between service providers and visitors are also analysed. Antón et al. (2017), for example, stated that prior visitor knowledge is considered to be an important driver for active participation and interaction during museum visits. Through intangible heritage, museum sites can also design experiences related to traditional culinary techniques (Ross et al., 2017). Further, cocreation is often investigated under the service-dominant logic, a marketing approach, which analyses tourists creating value with businesses through intangible aspects (e.g. sharing information) (Sfandla and Björk, 2013). Tourists, who participate in co-creation processes through involvement, time and effort spent, leverage the value of the experience, while producing it (Prebensen et al., 2013).

\section{Food-and-wine tourism and the co-creation experience}

From an academic point of view, Hall et al. (2003) have advanced the definition of food tourism as an experiential trip for primary and secondary food producers, food festivals and fairs, farmers markets, cooking shows, tastings or any food-related tourism activity. To broaden this conceptualisation, the international leading organisation in the field of tourism the World Tourism Organisation - expands on that definition in that "tourists and visitors who plan their trips partially or totally in order to taste the cuisine of the place or to carry out activities related to gastronomy" (UNWTO, 2012, p. 7). For the contemporary food-and-wine tourists, local cuisine, environment, health, lifestyle, regionalism, rurality, authentic foods and the novelty element are fundamental components in providing memorable experiences (Mason and O'Mahony, 2007; Stone et al., 2017). The authenticity of the food experiences has been attested, has a significant attribute of the experience (Antón et al., 2019) and its perceived quality influences the buying behaviour of local foods by tourists (Rahman et al., 2018). These elements are promoted in well-established food-and-wine countries such as Italy, France, South Africa and Thailand (Figueroa and Rotarou, 2018). On the other hand, food waste in tourism-related activities is raising concerns about the environmental sustainability of destinations (Gretzel et al., 2019).

Food tourism includes the countries' wine culture, and for that reason, wine tourism literature is vast [see, for example, Getz and Brown (2006) and Charters and Ali-Knight (2002)]. Wine tourism is an integrative part of food tourism experiences (OECD, 2012), despite its distinct territorial dynamics and supporting structures (Rachão et al., 2019). A widely accepted definition of wine tourism is proposed by Hall et al. (2000), which embodies wineries visitation, attending wine festivals and tasting/experiencing wines. As food and wine tourists want to learn something new while having fun (Goossens, 2000; Leri and Theodoridis, 2019), and increasingly want to become involved in the production of food (Richards, 2012), food and wine events should offer active participation (Getz and Robinson, 2014). This active participation through cooking classes, wine-making workshops, harvesting activities, grape crushing, among others, may foster the escapist and educational experience (Quadri-Felitti and Fiore, 2014; Thanh and Kirova, 2018). Co-creation, in this context, may be represented by taking part in practical activities of the food-and-wine preparation processes. As a matter of fact, partaking in wine-related activities and adding a novelty component are crucial factors for a memorable experience (Saayman and van der Merwe, 2015; Williams et al., 2019). Thus, the novelty as a touristic element (Stone et al., 2017) plays an important role in tourists' memorabilia (Kim et al., 2012; Bertella, 2014), tends to influence the satisfaction of the tourists (Prebensen and Xie, 2017), leads to higher 
food involvement (Caber et al., 2018) and it is a major motivation to travel (Zatori and Beardsley, 2017).

Despite various debates on the role of co-creation in tourism, the construct - an informed, scientific idea developed to describe or explain behaviour (Nunnally and Bernstein, 1994) - of co-creation remains, in some way, unclear. The issue of conceptualisation may have serious practical implications for private and public tourism organisations in understanding tourists' motivations (Neuhofer et al., 2012). Although the literature addresses the complex processes of co-creation within the most diverse settings such as ICTs, peer-to-peer (guest-host) and cultural (Binkhorst and Den Dekker, 2009; Neuhofer et al., 2012; Sfandla and Björk, 2013; Campos et al., 2018), to the best of our knowledge, scarce research has been done on the conceptualisation of the co-creation construct and how it can be used in food-and-wine tourism experiences. Recent studies relate food-and-wine tourism experiences combined with cultural activities, yet the level of tourists' co-creation (active participation) is not discussed. As claimed by Festa et al. (2015), wine tourists are already perceived as prosumers of the winery experience, nevertheless further research is needed on the active participation of tourists motivated by wine-related activities, as well as food offerings in general (Hwang and Seo, 2016).

\section{Methodology}

To explore tourists' perceptions on the co-creation construct and their willingness to active participation in food-and-wine experiences, a qualitative research strategy was chosen because of its suitability to reveal how consumers perceive new concepts (Roininen et al., 2006) and to the subjectivity of the co-creation of experiences (Wilson and Hollinshead, 2015). Qualitative research is, as well, more appropriate for understanding tourism experiences (Holbrook, 2006), and co-creation experiences in particular (Rihova et al., 2015).

\section{Focus group}

The focus group technique was chosen as it is highly efficient to extract information on attitudes and motivations (Clark et al., 2007), through free-flowing discussion (Veal, 2006), encouraged by the moderator. Although there is no fixed number for a focus group, there should be enough participants to generate discussion, which can range from five to ten (Dwyer et al., 2012).

The participants for the focus group of this research were recruited through travel and hospitality networks. The sampling frame was defined as people over 18 years old, travelling in Northern Portugal not for business and professional purposes, and whose travel included, at least, one overnight stay. The focus group was held in the Vinho Verde wine region of Northern Portugal that typically promotes food-and-wine tourism, and took place in 2018 during peak summer season (July). The focus group session was video-taped and transcribed verbatim by the moderator, the main researcher of the study. The content analysis was prepared through the software package QSR International NVIVO 11. A focus group interview guide, divided into three sections, was prepared to assist the moderator in leading the focus group participants in their discussion (Krueger and Casey, 2000). Topics included in the focus group guide were:

- perceptions on the co-creation construct (word association technique);

- regions/countries where food-and-wine experiences took place;

- type of food-and-wine activities experimented;

- preferred type of food-and-wine experiences performed;

- willingness to participate in a food and in a wine experience (with different stages); and

- socio-demographic profile. 
To understand whether interviewees were interested in actively participating (level of intervention) in the different stages of food-and-wine experiences, two experiences were created. Both were based on existing experiences available in accommodation establishments, with some minor adjustments. For the food experience, two options for which tourists would prefer to take cooking classes were added: "Cooking class with a chef" and "Cooking class with local people". For the wine experience, brief explanations on the different technical stages were added to provide additional information to participants.

A word association technique was used as it is a method commonly used to explore concepts (Prebensen, 2007; Hosany and Gilbert, 2010), through the assessment of the first thoughts and/or words that come to the mind of the respondents (Mesías and Escribano, 2018; Roininen et al., 2006; Verma and Chandra, 2018). As co-creation is a concept perceived by tourists, the inductive content analysis was used as the themes were derived from the data collected on the stimulus word "co-creation" and they were not imposed by a defined framework (Mehmetoglu and Dann, 2003). Therefore, under an interpretative research approach, data exploration led to the construction of a theory (Bustard et al., 2018; Clark et al., 2007).

During the initial phase, the elicited associations were subjected to open coding performed to identify major themes relative to the study. Constructed on similarity, words were grouped together using the triangulation of researchers' technique, the research team developed to build up thematic categories, first in an independent way and then followed by consensus (Verma and Chandra, 2018). Thematic categories were subjected to a process of continuous comparison. The triangulation of researchers was used to enhance the reliability of the findings (Decrop, 1999; Dwyer et al., 2012). A pilot study of ten face-to-face semistructured interviews was used to assess the flow of the questions, refine questions wording and eliminate any weakness in the quality of the categories.

\section{Semi-structured interviews}

Because of difficulties encountered to gather tourists for implementing further focus groups, individual face-to-face semi-structured interviews were introduced. The interview script consisted of 12 questions divided into 3 sections following the structure of the focus group interview but from an individual approach. The convenience sampling technique was chosen as tourists were selected because of their convenient accessibility (Altinay and Paraskevas, 2008). Clark et al. (2007, p. 87) adds that "convenience sampling means taking as a sample whoever is available to receive the administration of the research instrument" (a questionnaire and an interview). For this research, tourists were approached in small accommodation facilities during periods of relaxation such as reading by the pool or consuming beverages on the terrace. The semi-structured interviews were conducted in August and September 2018.

Regardless of the common agreement that 1 to 30 informants are suitable for qualitative analysis (Bengtsson, 2016), the 14 semi-structured interviews turn out to be adequate, mainly because of the merit of face-to-face interviews that allowed longer answers and supplementary questions (Clark et al., 2007), and whenever the researcher felt that data saturation was reached (Altinay and Paraskevas, 2008), she proceeded to the next question. The complete profiles of the participants of the focus group and structured interviews are described in Table I.

The semi-structured interviews also involved a content analysis of the tourist responses. Content analysis is a technique increasingly used in tourism research (Veal, 2006), particularly to develop valid contextual inferences from texts or other objects (Krippendorff, 2004). 
Table I Profile of the interviewees

\begin{tabular}{|c|c|c|c|c|}
\hline Interviewees & Gender & Age (years) & Country of residence & Occupation \\
\hline \multicolumn{5}{|c|}{ Focus group (FG) } \\
\hline FG1 & Female & $18-35$ & Switzerland & Specialist in intellectual and scientific activities \\
\hline FG2 & Female & $18-35$ & Switzerland & Other: Physiotherapist \\
\hline FG3 & Female & $36-45$ & Germany & Specialist in intellectual and scientific activities \\
\hline FG4 & Female & $36-45$ & Germany & Specialist in intellectual and scientific activities \\
\hline FG5 & Female & $46-65$ & Germany & Specialist in intellectual and scientific activities \\
\hline \multicolumn{5}{|c|}{ Semi-structured interviews (SI) } \\
\hline SI6 & Male & $18-35$ & Mexico & Specialist in intellectual and scientific activities \\
\hline SI7 & Female & $18-35$ & Germany & Administrative staff \\
\hline $\mathrm{SI} 8$ & Female & $18-35$ & Russia & Other: Yoga teacher \\
\hline SI9 & Female & $46-65$ & Germany & Specialist in intellectual and scientific activities \\
\hline SI10 & Female & $18-35$ & Germany & Administrative staff \\
\hline SI11 & Male & $18-35$ & Israel & Specialist in intellectual and scientific activities \\
\hline SI12 & Male & $18-35$ & Austria & Administrative staff \\
\hline SI13 & Female & $18-35$ & Austria & Administrative staff \\
\hline SI14 & Male & $18-35$ & Germany & Specialist in intellectual and scientific activities \\
\hline SI15 & Female & $18-35$ & Germany & Administrative staff \\
\hline SI16 & Female & $18-35$ & Germany & Skilled industry workers \\
\hline SI17 & Male & $>65$ & Australia & Specialist in intellectual and scientific activities \\
\hline SI18 & Female & $>65$ & Australia & Specialist in intellectual and scientific activities \\
\hline SI19 & Female & $18-35$ & Portugal & Graduate student \\
\hline
\end{tabular}

\section{Findings}

\section{Tourists' perceptions of the "co-creation" construct}

Using an interpretative method for data analysis (Bustard et al., 2018; Massa and Bédé, 2018), the study started with eliciting participants to write down the first associations related to "co-creation", and after categorisation, seven themes emerged as displayed in Table II. The emergent themes will be further analysed to find out how specific actions in each of the seven co-creation dimensions might benefit co-creative foodand-wine experiences.

\section{Theme 1 - social interaction}

Results from the thematic analysis showed that "social interaction" is a representative theme, encapsulating diverse associations; in total 22 mentions, in which "sharing" and "team work" were emphasised by the respondents. In fact, social interaction is an indispensable factor in adding value to the tourism experience. Interacting with others, either tourists, residents or tourism professionals while travelling, promotes knowledge and more authentic experiences through relational contact with others.

\section{Theme 2 - creativity}

The subsequent theme found was "creativity", in which associations such as "arts", "combination of traditional with new perspectives" and "talent" emerged. Creativity in tourism is reflected in the return to the "origins", in more informal networks, social atmospheres and reinvented traditional places. The development of alternative forms of travel and accommodation (e.g. home swapping; Airbnb) mirrors the changing patterns of consumption habits. Tourists are looking to develop their skills (painting, sporting and learning languages) while travelling, avoiding mainstream cultural tourism forms. 
Social interaction

Creativity

Social sustainability

Environmental awareness

Novelty seeking

Memorable experiences

Enjoyment

Business-plan

Discussions

No hierarchy

No idea what co-creation is

Progressive form of tourism association; collaboration; cooperation; couple; co-workers; doing something with somebody; group; learn; making something new together; not feeling alone; partners; partner or family; share; sharing**; synergy; team; team work $^{* *}$; together; with a friend; working together arts; a combination of traditional with new perspectives; creating something with natural products; creativity**; designing; manifestation; own ideas; passion; talent; vision assistance; creating new forms of communities; community; help**; helping each other; helping poor people; inclusive work; mixed generations of people; organising trips with local people

agriculture; clean up nature; ecological process; nature; planting; recycling; to be more responsible for nature; upcycling techniques

discover; diversity; experiencing new things; getting to know different cultures; meeting new people; new product; open; openness (for new ideas) collecting moments; creating memories; meaningfulness; taking pictures friendship; fun; happiness; harmony

*

$*$ *

Notes: Participants could state more than one association; *floating ideas with no connections to others; ${ }^{* *}$ most representative

\section{Theme 3- social sustainability}

The word association test generated references such as "helping each other", "inclusive work", "organising trips with local people" and "creating new forms of communities". This theme is strongly linked to "social interaction", referring to the interactions between tourists and local residents. However, this new relational form of travel in which tourists seeks to connect to local people poses challenges in defining what is "local" in a globalised world.

\section{Theme 4- environmental awareness}

There was a consensus among the interviewees that co-creation could be associated with environmental practices ranging from recycling to upcycling ideas. Progressively more people are concerned about environmental issues, both in their usual residence and while they are travelling, sometimes engaging in collective cleaning up waste actions, particularly in natural sites and on coastlines. This was evident in statements such as "To be more responsible to nature" (FG1) and "Clean up nature by collecting garbage" (FG5).

\section{Theme 5- novelty seeking}

The tourists' perceptions regarding co-creation led to the "novelty seeking" theme. As disclosed in Table IV, interviewees seemed to associate co-creation to be open for innovation, emphasising the pursuit of "discover", "experiencing new things", "getting to know different cultures" and "openness for new ideas".

\section{Theme 6-memorable experiences}

Tourists travel to several places, and they particularly recall and tell others about their positive experiences. They also tend to consume numerous services that might have an impact on their memory. This was expressed in associations such as "collecting moments", "creating memories" and "meaningfulness". 


\section{Theme 7 - enjoyment}

Co-creation was, however, less often associated with the enjoyment theme. Tourists are, in fact, motivated by hedonic benefits when it comes to travel experiences. For that reason, the co-creation construct evoked emotive associations such as "friendship", "fun", "happiness" and "harmony".

\section{Food-and-wine tourism experiences}

The interviewees, when enquired about their participation in food-and-wine tourism activities, mentioned that most of their previous experiences were related to wine and olive oil tasting and tours to whiskey and rum distilleries. These activities were mainly done in countries where food-and-wine tourism is already well-established, such as Austria, Italy, Spain, New Zealand, South Africa and Thailand:

I was in some whiskey distilleries in Scotland and rum in Cuba, in Columbia and Nicaragua. [FG1]

When I was in New Zealand, I visited a famous wine region, and [.. .] once a month a restaurant invites a wine producer from the region, and he gives tips about the wine which goes best with the meal. [FG2]

When interviewees were questioned about what they liked most, the atmosphere, the landscape and learning were the most significant attributes in the experience. And, when they were not particularly appealed by wine, they showed interest in learning about winemaking processes and food-and-wine pairing:

The atmosphere, the area, the vineyards. [FG4]

I just liked to see the procedure, the process from the beginning to have rum in a bottle. [FG1]

We were driving along the coastline, seeing the vineyards, the old houses, relaxing in the gardens, having some wine and bread, the landscape. [FG5]

I am not a wine drinker, but I just enjoyed the atmosphere and learned how they got into wine. [FG2]

Nevertheless, part of the interviewees never tried or simply was not motivated to participate in food-and-wine activities during their holiday, demonstrating some lack of knowledge regarding this type of experiences:

I am interested in local food, but food-and-wine is not my primary reason to travel. [SI16]

I have never done such a thing in my life. I am not a wine drinker. I am vegetarian. And I don't like cooking. [FG3]

Never heard about it until now. Maybe I would try it. [SI15]

One of the respondents [FG3] showed another facet of the post-modern tourist that has to be taken into account: changing eating habits because of the growing number of vegetarians, healthy people following other diets and people with food allergies and intolerance.

\section{Level of interest in actively participating in different stages of food-and-wine experiences while travelling}

Table III displays the level of interest of tourists who actively participate in the food and wine experiences. With regard to the wine experience, in this study, wine tasting, learning about 
Table III Level of interest in active participation (based on the focus group questionnaire section and semi-structured interviews, $n=19)$

Level of interest in active participation (\%)

Wine experience

A brief introduction to wines (theory)

Wine tasting

Blend construction (mixing varieties of wine grapes)

Bottling

Coiling (place the cork in the bottle)

Encapsulation (place the capsule that surrounds the bottleneck)

Label design (drawing of the label)

Final photo of the experience

Food experience

Receive an explanation of food products and ingredients used

Pick your own ingredients

Cooking class with chef

Cooking class with local people

Eat the meal you cooked yourself
$37 \%$ interested

$42 \%$ very interested

$32 \%$ interested

$26 \%$ somewhat interested

$32 \%$ neutral

$37 \%$ not at all interested

$32 \%$ interested

$26 \%$ neutral

$47 \%$ very interested

$47 \%$ very interested

$32 \%$ very interested

$47 \%$ very interested

$47 \%$ very interested

wines (brief theoretical introduction to wines) and blending construction (mixing the wine grape varieties) were the stages in which interviewees showed a higher level of interest to actively participate. Additionally, the stage of label design (drawing the front bottle label) also collected a significant level of interest. Conversely, the more technical stages of the wine experience such as bottling, coiling (place cork in the bottle) and encapsulation (place the capsule that surrounds the bottleneck) seemed to have the least interest level to actively participate.

Overall, the food experience obtained a higher level of interest from the interviewees who were willing to actively participate in all its stages, something that was not the case when compared with the wine experience. Also, the interviewees demonstrated a higher interest in having cooking classes with local people rather than having cooking classes with professionals (chefs). This might be explained by the ages of the interviewees (18-35 years old), fitting into the millennial generational cohort (18-37 years old).

\section{Discussion}

\section{Tourists' perceptions of the "co-creation" construct}

The study results from the word association technique showed that "social interaction" is a representative theme as referred in the literature review (Rihova et al., 2015; Reichenberger, 2017; Schuckert et al., 2018), and the co-created relationships during social interaction are one of the attributes linked to generating memorable gastro-tourism experiences (Williams et al., 2019). The study found that applying creativity to redesign alternative experiences (Ross et al., 2017) might facilitate a lasting memory value (Upadhya and Vij, 2016) as was discussed in the literature review section.

The results also reveal that the integration of the activities into daily life (Ngamsirijit, 2014), namely, to involve with local communities while seeking for experiences which are perceived as authentic, is an important attribute. As a matter of fact, this way of processing echoes the post-modern tourist consumption behaviour, as tourists now ache for making part of the community visited (Paulauskaite et al., 2017). Furthermore, environmental awareness among tourists is growing and considered as an important attribute in the hotel choice decision (Adongo et al., 2018; Verma and Chandra, 2018).

The identified theme of novelty seeking is mentioned in previous studies (Kim et al., 2012; Bertella, 2014; Stone et al., 2017) and is deeply connected to the enhancement of 
memorable tourism experiences. Besides seeking novelty, tourists are seeking hedonic benefits which are explained into enjoyment, fun and excitement (Goossens, 2000; Leri and Theodoridis, 2019), and might be enriched through the co-creation of social interactions (Reichenberger, 2017) as described by interviewees.

\section{Food-and-wine tourism experiences}

The findings of this study support previous work by Thanh and Kirova (2018) who examined the main type of activities undertaken by tourists in food-and-wine related travels, such as wine and olive oil tasting and vineyard tours. Results of this study also show that Austria, Italy, Spain, New Zealand, South Africa and Thailand were the countries preferred by the interviewees to explore food-and-wine experience which is consistent with the literature (Getz and Brown, 2006; Figueroa and Rotarou, 2018).

The study also confirmed that whoever creates food-and-wine experiences today, has to consider this major influencer of travel and eating behaviours: the new tourist takes health concerns in consideration when he decides what he will do (Mak et al., 2012; Dilek and Fennell, 2018). The study further indicates that non-wine related activities, such as the atmosphere, the landscape and learning, were the most significant attributes in the experience. This reflects the changing wine consumption behaviour of younger consumers; as a matter of fact, a winery visitation experience is more successful when it includes nonwine related activities, as enjoying the scenery and food, dining and socialising (Stergiou, 2018). Another unexpected result was that the interviewees spontaneously and explicitly ask for the inclusion of some of the principles of sustainable development and thus, indirectly, appreciate experiences that incorporate something of the sustainable development goals.

\section{Level of interest in actively participating in different stages of food-and-wine experiences while travelling}

Finally, it was identified that tourists showed more interest in actively participating in less technical activities, in this case rather, in food activities than in wine experiences. As the literature review revealed, there is a need to define which stages of the tourism activities require co-creation and to what level tourists prefer co-creation (Hwang and Seo, 2016).

The fact that interviewees showed a tendency to prefer food activities echoes the findings of Williams et al. (2019), who reported tourists' increasing interest in food-related activities, within a culinary/gastronomic context. Moreover, these experiential food experiences, combined with local human capital, local knowledge and creativity, provide substance for "authentic" and signature local experiences, and this is precisely what millennials prefer, as they are on the search for authentic, local and non-touristic experiences (Stone et al., 2017).

\section{The co-creation experience in tourism: a proposed model}

As a result of this exploratory research, a model for the co-creation of food-and-wine tourism experiences is proposed (Figure 1), which suppliers might want to implement, enabling their clients to engage into new relationships.

The model presented in this study centres on seven categories which were informed by the theoretical underpinnings and the empirical findings of this study: social interaction, novelty, creativity, social sustainability, environmental awareness, enjoyment and memorable experiences. The first layer of the model joins the first five categorical dimensions (social interaction, novelty, creativity, social sustainability and environmental awareness) of the cocreation conceptualisation on a same level of importance. These dimensions can improve the hedonic benefits (enjoyment) as well as the memorabilia of the experiences (memorable experience), shown in the second layer. Thus, the categories of the second layer derive 


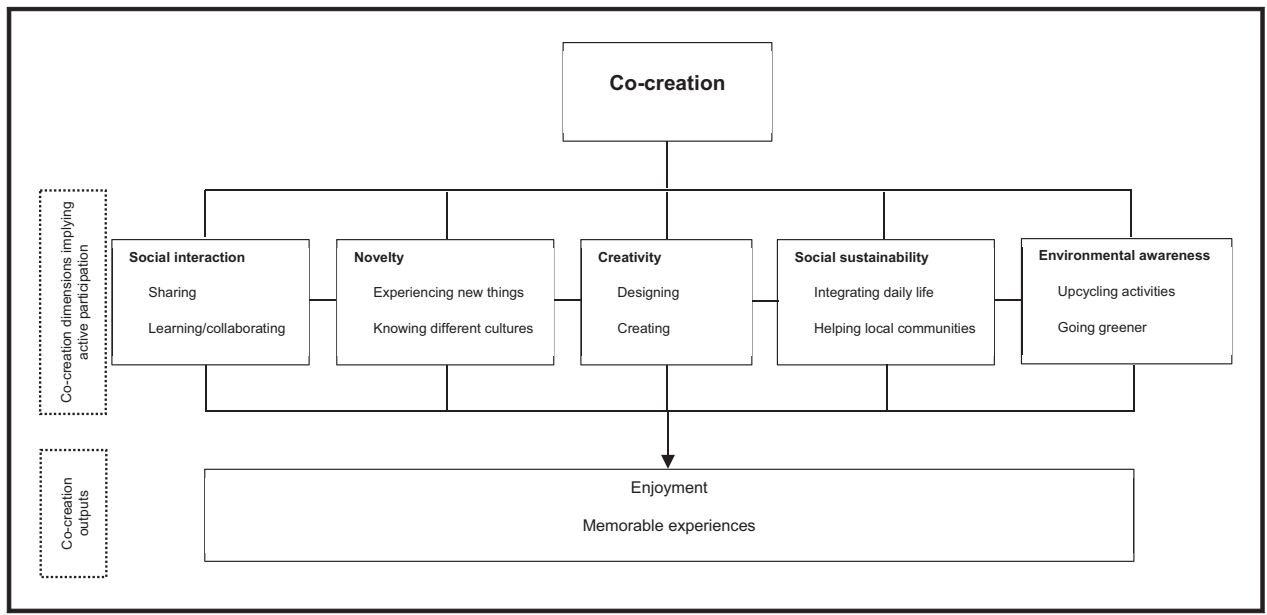

directly from the fulfilment of the categories of the first layer. Based on the literature review and the empirical findings resulting from the semi-structured interviews and focus group content analysis, Figure 1 illustrates how five of the dimensions of the co-creation construct can be transformed into guidelines/principles for tourism professionals interested in conceptualising or improving co-creative tourism experiences.

The proposed model presents a new approach to the development of food-and-wine tourism activities based on co-creation. It indicates that it is crucial to recognise the seven dimensions displayed when designing and delivering co-creative food-and-wine experiences for generating value co-creation.

Thus, while a standard wine and/or food tasting in a winery or restaurant is a usual tourism product model, involving interactions, experiencing something new, participating into locals' daily life, co-creating activities, being environmentally responsible to generate fun and memorable experiences call for greater input from tourism providers.

\section{Conclusion}

\section{Managerial and theoretical implications}

As a highly experiential and social way of exploring different cultures, more hands-on information about how to turn co-creative food-and-wine experiences even more appealing will certainly interest managers willing to capture and/or maintain the attention of their clients. This could be done in the form of encouraging social interaction with other participants and local service providers, the latter enabling their customers to creatively develop their own experience to suit their needs. Results show that the interviewees are more willing to actively participate in less technical food experiences. As such, destination stakeholders should take these factors into consideration when designing food-and-wine related experiences. Furthermore, business managers should include environmental practices into their experiences, making them visible for their customers, through upcycling activities (e.g. creative reuse of bottle corks) or reducing business waste, such as replacing water plastic bottles by drinking fountains along vineyards.

It is also suggested that managers should incorporate the social sustainability category in the new experiences they design. They might start investing in typical social entrepreneurship practices of the food industry that imply co-creation aspects (e.g. attending local farmers' markets and having local people teach how to cook traditional dishes) and thus increase their impact on society. 
From a theoretical perspective, this study reflects an attempt to offer a wider understanding of the co-creation construct. The research findings not only emphasise the significance of understanding tourists' co-creation conceptualisation, but also indicate the importance of integrating the creativity and environmental awareness dimensions. Additionally, the findings of the content analysis suggest the willingness of the tourists to get involved in experiences that can make express themselves by taking an active and creative role.

\section{Limitations and future research}

This study has some limitations. Its exploratory nature makes the data not generalisable. Therefore, the findings need further quantitative validation. Although the food and wine experiences were created based on existing experiences, they were composed of a different number of stages (non-uniform), which may complicate further statistical analysis (comparisons).

Results also show that tourists were involved in different types of food and beverages experiences. Further research is recommended to explore how food tourism experiences, e.g. olive oil, or beverages experiences using beer or whiskey, might differ in terms of creative design. Thus, assessing the optimal level of actual co-creation intervention in different contexts could impact the quality in designing food-and-wine tourism experiences.

Findings suggest an increasing healthy eating and vegetarianism phenomenon. In fact, people now have much more diverse food consumption habits: from vegetarianism and veganism to intolerance to lactose and gluten, among others. Future research should investigate the relevance of how low-processed products, biological wines and other organic products (e.g. olive oil) might influence the demand on food-and-wine tourism products/services. Also, more research is needed on eating habits and tourism consumption behaviour to improve the daily customer-interactive-operations of food-andwine establishments with other tourism-related businesses.

\section{References}

Adongo, C.A., Taale, F. and Adam, I. (2018), "Tourists' values and empathic attitude toward sustainable development in tourism”, Ecological Economics, Vol. 150, pp. 251-263.

Alonso, A.D. and Yi, A. (2010), "Wine tourism development in emerging Western australian regions", International Journal of Contemporary Hospitality Management, Vol. 22 No. 2, pp. 245-262.

Alonso, A.D., Bressan, A., Shea, M.O. and Krajsic, V. (2015), "Perceived benefits and challenges to wine tourism involvement: an international perspective", International Journal of Tourism Research, Vol. 17 No. 1, pp. 66-81.

Altinay, L. and Paraskevas, A. (2008), Planning Research in Hospitality and Tourism, Routledge Taylor \& Francis Group, London.

Antón, C., Camarero, C. and Garrido, M.J. (2017), "Exploring the experience value of museum visitors as a co-creation process", Current Issues in Tourism, Vol. 21 No. 12, pp. 1406-1425.

Antón, C., Camarero, C., Laguna, M. and Buhalis, D. (2019), "Impacts of authenticity, degree of adaptation and cultural contrast on travellers' memorable gastronomy experiences", Journal of Hospitality Marketing \& Management, Vol. 28 No. 7, pp. 743-764.

Bengtsson, M. (2016), "How to plan and perform a qualitative study using content analysis", NursingPlus Open, Vol. 2, pp. 8-14.

Bertella, G. (2014), "The co-creation of animal-based tourism experience", Tourism Recreation Research, Vol. 39 No. 1, pp. 115-125.

Bertella, G. (2015), "Celebrating the family abroad: the wedding tourism experience", Annals of Leisure Research, Vol. 18 No. 3, pp. 397-413.

Bertella, G., Cavicchi, A. and Bentini, T. (2018), "The reciprocal aspect of the experience value: tourists and residents celebrating weddings in the rural village of Petritoli (Italy)", Anatolia, Vol. 29 No. 1, pp. 52-62. 
Binkhorst, E. and Den Dekker, T. (2009), “Agenda for Co-Creation tourism experience research”, Journal of Hospitality Marketing \& Management, Vol. 18 Nos 2/3, pp. 311-327.

Bruwer, J. (2003), "South African wine routes: some perspectives on the wine tourism industry's structural dimensions and wine tourism product”, Tourism Management, Vol. 24 No. 4, pp. 423-435.

Bruwer, J., Prayag, G. and Disegna, M. (2018), "Why wine tourists visit cellar doors: segmenting motivation and destination image", International Journal of Tourism Research, Vol. 20 No. 3, pp. 355-366.

Bustard, J.R.T., Bolan, P., Devine, A. and Hutchinson, K. (2018), "The emerging smart event experience: an interpretative phenomenological analysis", Tourism Review, Vol. 74 No. 1, pp. 116-128.

Caber, M., Yilmaz, G., Kiliçarslan, D. and Öztürk, A. (2018), "The effects of tour guide performance and food involvement on food neophobia and local food consumption intention", International Journal of Contemporary Hospitality Management, Vol. 30 No. 3, pp. 1472-1491.

Campos, A.C., Mendes, J., do Valle, P.O. and Scott, N. (2018), "Co-creation of tourist experiences: a literature review", Current Issues in Tourism, Vol. 21 No. 4, pp. 369-400.

Charters, S. and Ali-Knight, J. (2002), "Who is the wine tourist?", Tourism Management, Vol. 23 No. 3 , pp. 311-319.

Charters, S. and Menival, D. (2011), "Wine tourism in champagne", Journal of Hospitality \& Tourism Research, Vol. 35 No. 1, pp. 102-118.

Charters, S., Fountain, J., Fish, N. (2009), "You felt like lingering ....": experiencing "real" service at the winery tasting room", Journal of Travel Research, Vol. 48 No. 1, pp. 122-134.

Chen, Z. (2018), "A pilot study of the co-creation experience in traditional Cantonese teahouses in Hong Kong", Journal of Heritage Tourism, Vol. 13 No. 6, pp. 506-527.

Chien, S., Wu, J. and Huang, C. (2018), "We made, we trust": coproduction and image congruence in the food-tourism factories", Asia Pacific Management Review, Vol. 23 No. 4, pp. 310-317.

Clark, M., Riley, M., Wilkie, E. and Wood, R.C. (2007), Researching and Writing Dissertations in Hospitality and Tourism, Thomson Learning, London.

Decrop, A. (1999), "Triangulation in qualitative tourism research", Tourism Management, Vol. 20 No. 1, pp. 157-161.

Dilek, S.E. and Fennell, D.A. (2018), "Discovering the hotel selection factors of vegetarians: the case of Turkey", Tourism Review, Vol. 73 No. 4, pp. 492-506.

Dwyer, L., Gill, A. and Seetaram, N. (2012), Handbook of Research Methods in Tourism Quantitative and Qualitative Approaches, Edward Elgar, Cheltenham.

Eide, D., Fuglsang, L. and Sundbo, J. (2017), "Management challenges with the maintenance of tourism experience concept innovations: toward a new research agenda", Tourism Management, Vol. 63, pp. 452-463.

Festa, G., Vrontis, D., Thrassou, A. and Ciasullo, M.V. (2015), "A value co-creation model for wine tourism", International Journal of Management Practice, Vol. 8 No. 3, pp. 247-267.

Figueroa, B.E. and Rotarou, E.S. (2018), "Challenges and opportunities for the sustainable development of the wine tourism sector in Chile", Journal of Wine Research, Vol. 29 No. 4, pp. 243-264.

Garibaldi, R. and Pozzi, A. (2018), "Creating tourism experiences combining food and culture: an analysis among italian producers", Tourism Review, Vol. 73 No. 2, pp. 230-241.

Getz, D. and Brown, G. (2006), "Critical success factors for wine tourism regions: a demand analysis", Tourism Management, Vol. 27 No. 1, pp. 146-158.

Getz, D. and Robinson, R.N.S. (2014), "Foodies and food events", Scandinavian Journal of Hospitality and Tourism, Vol. 14 No. 3, pp. 315-330.

Goossens, C. (2000), "Tourism information and pleasure motivation", Annals of Tourism Research, Vol. 27 No. 2, pp. 301-321

Gretzel, U., Murphy, J., Pesonen, J. and Blanton, C. (2019), "Food waste in tourist households: a perspective article", Tourism Review

Hall, C.M., Sharples, L., Michell, R., Macionis, N. and Cambourne, B. (2003), Food Tourism around the World, Butterworth-Heinemann, Oxford. 
Hall, C.M., Longo, A.M., Mitchell, R. and Johnson, G. (2000), "Wine tourism in New Zealand", in Hall, C.M., Sharples, L., Cambourne, B. and Macionis, N. (Eds), Wine Tourism around the World: Development, Management and Markets, Elsevier Science, Oxford, pp. 150-176.

Holbrook, M.B. (2006), "Consumption experience, customer value, and subjective personal introspection: an illustrative photographic essay", Journal of Business Research, Vol. 59 No. 6, pp. 714-725

Hosany, S. and Gilbert, D. (2010), "Measuring tourists' emotional experiences toward hedonic holiday destinations", Journal of Travel Research, Vol. 49 No. 4, pp. 513-526.

Hwang, J. and Seo, S. (2016), "A critical review of research on customer experience management: theoretical, methodological and cultural perspectives", International Journal of Contemporary Hospitality Management, Vol. 28 No. 10, pp. 2218-2246.

Kim, J., Ritchie, J.R.B. and Mccormick, B. (2012), "Development of a scale to measure memorable tourism experiences", Journal of Travel Research, Vol. 51 No. 1, pp. $12-25$.

Krippendorff, K. (2004), Content Analysis: An Introduction to Its Methodology, 2nd ed., SAGE, Thousand Oaks.

Krueger, R.A. and Casey, M.A. (2000), Focus Group. A Practical Guide for Applied Research, 3rd ed., SAGE, London.

Leri, I. and Theodoridis, P. (2019), "The effects of the winery visitor experience on emotions, satisfaction and on post-visit behaviour intentions”, Tourism Review, Vol. 74 No. 3, pp. 480-502.

Long, L.A. (1998), Culinary Tourism, The University Press of KY, Lexington.

Mak, A.H.N., Lumbers, M., Eves, A. and Chang, R.C.Y. (2012), "Factors influencing tourist food consumption", International Journal of Hospitality Management, Vol. 31 No. 3, pp. 928-936.

Mason, R. and O'Mahony, B. (2007), "On the trail of food and wine: the tourist search for meaningful experience", Annals of Leisure Research, Vol. 10 Nos 3/4, pp. pp. 498-517.

Massa, C. and Bédé, S. (2018), "A consumer value approach to a holistic understanding of the winery experience", Qualitative Market Research: An International Journal, Vol. 21 No. 4, pp. 530-548.

Mathis, E.F., Kim, H.L., Uysal, M., Sirgy, J.M. and Prebensen, N.K. (2016), "The effect of co-creation experience on outcome variable", Annals of Tourism Research, Vol. 57, pp. 62-75.

Mehmetoglu, M. and Dann, G.M.S. (2003), "ATLAS/ti and content/semiotic analysis in tourism research", Tourism Analysis, Vol. 8 No. 1, pp. 1-13.

Mesías, F.J. and Escribano, M. (2018), "Projective techniques", in Ares G. \& Varela, P. (Eds), Methods in Consumer Research, Volume 1: New Approaches to Classic Methods, Elsevier, Badajoz, pp. 79-99.

Michael, M., Jorge, E. and Esteban, C. J. D. (2009), "Has the experience economy arrived?", International Journal of Tourism Research, Vol. 11 No. 2, pp. 201-216.

Morgan, M. (2007), "We're not the barmy army!': reflections on the sports tourist experience", International Journal of Tourism Research, Vol. 9 No. 5, pp. 361-372.

Mossberg, L. (2008), "Extraordinary experiences through storytelling", Scandinavian Journal of Hospitality and Tourism, Vol. 8 No. 3, pp. 195-210.

Neuhofer, B., Buhalis, D. and Ladkin, A. (2012), "Conceptualising technology enhanced destination experiences", Journal of Destination Marketing \& Management, Vol. 1 Nos No. 1-2, pp. 36-46.

Neuhofer, B., Buhalis, D. and Ladkin, A. (2014), "A typology of technology-enhanced tourism experiences", International Journal of Tourism Research, Vol. 16 No. 4, pp. 340-350.

Ngamsirijit, W. (2014), "Value creation in creative tourism: co-creation through data mining", International Journal of Intelligent Enterprise, Vol. 2 Nos 2/3, pp. 255-276.

Nunnally, J.C. and Bernstein, I.H. (1994), Psychometric Theory, 3rd ed., McGraw-Hill, New York, NY.

O'dell, T. (2007), "Tourist experiences and academic junctures", Scandinavian Journal of Hospitality and Tourism, Vol. 7 No. 1, pp. 34-45.

OECD (2012), "Food and tourism experience, the OECD Korea workshop", OECD Studies on Tourism, OECD Publishing, available at: www.oecd.org/cfe/tourism/foodandthetourismexperiencetheoecd-korea Iworkshop.htm (accessed on 5 May 2017). 
Paulauskaite, D., Powell, R., Coca-Stefaniak, J.A. and Morrison, A.M. (2017), "Living like a local: authentic tourism experiences and the sharing economy", International Journal of Tourism Research, Vol. 19 No. 6, pp. 619-628.

Prebensen, N.K. (2007), "Exploring tourists' images of a distant destination", Tourism Management, Vol. 28 No. 3, pp. 747-756.

Prebensen, N.K. and Xie, J. (2017), "Efficacy of co-creation and mastering on perceived value and satisfaction in tourists' consumption", Tourism Management, Vol. 60, pp. 166-176.

Prebensen, N.K., Vitters $\varnothing$, J. and Dahl, T.I. (2013), "Value co-creation significance of tourist resources", Annals of Tourism Research, Vol. 42, pp. 240-261.

Quadri-Felitti, D.L. and Fiore, A.M. (2014), "Destination loyalty: effects of wine tourists' experiences, memories, and satisfaction on intentions", Tourism and Hospitality Research, pp. 1-16.

Rachão, S., Breda, Z., Fernandes, C. and Joukes, V. (2019), "Food tourism and regional development: a systematic literature review", European Journal of Tourism Research, Vol. 21, pp. 33-49.

Rahman, M.S., Zaman, M.H., Hassan, H. and Wei, C.C. (2018), "Tourist's preferences in selection of local food: perception and behavior embedded model”, Tourism Review, Vol. 73 No. 1, pp. 111-132.

Reichenberger, I. (2017), "C2C value co-creation through social interactions in tourism", International Journal of Tourism Research, Vol. 19 No. 6, pp. 629-638.

Richards, G. (2012), "Food and the tourism experience: major findings and policy orientations", in Dodd D. (Ed.), Food and the Tourism Experience, OECD, Paris, pp. 13-46.

Rihova, I., Buhalis, D., Beth, M. and Moital, M. (2018), "Customer-to-customer co-creation practices in tourism: lessons from customer-dominant logic", Tourism Management, Vol. 67, pp. 362-375

Rihova, I., Buhalis, D., Moital, M. and Gouthro, M.B. (2015), "Conceptualising customer-to-customer value co-creation in tourism", International Journal of Tourism Research, Vol. 17 No. 4, pp. 356-363.

Rihova, I., Moital, M., Buhalis, D. and Gouthro, M.B. (2019), "Practice-based segmentation: taxonomy of C2C co-creation practice segments", International Journal of Contemporary Hospitality Management, Vol. 31 No. 9, pp. 3799-3818.

Roininen, K., Arvola, A. and Lähteenmäki, L. (2006), "Exploring consumers' perceptions of local food with two different qualitative techniques: laddering and word association", Food Quality and Preference, Vol. 17 Nos 1/2, pp. 20-30.

Ross, D., Saxena, G., Correia, F. and Deutz, P. (2017), "Archaeological tourism: a creative approach", Annals of Tourism Research, Vol. 67, pp. 37-47.

Saayman, M. and van der Merwe, A. (2015), "Factors determining visitors' memorable wine-tasting experience at wineries", Anatolia, Vol. 26 No. 3, pp. 372-383.

Schuckert, M., Peters, M. and Pilz, G. (2018), "The co-creation of host-guest relationships via couchsurfing: a qualitative study", Tourism Recreation Research, Vol. 43 No. 2, pp. 220-234.

Sfandla, C. and Björk, P. (2013), "Tourism experience network: co-creation of experiences in interactive processes", International Journal of Tourism Research, Vol. 15 No. 5, pp. 495-506.

Stamboulis, Y. and Skayannis, P. (2003), "Innovation strategies and technology for experience-based tourism”, Tourism Management, Vol. 24 No. 1, pp. 35-43.

Stergiou, D.P. (2018), "An importance-performance analysis of young people's response to a wine tourism situation in Greece”, Journal of Wine Research, Vol. 29 No. 4, pp. 229-242.

Stone, M.J., Soulard, J., Migacz, S. and Wolf, E. (2017), "Elements of memorable food, drink, and culinary tourism experiences", Journal of Travel and Tourism Marketing, pp. 1-12.

Thanh, T.V. and Kirova, V. (2018), "Wine tourism experience: a netnography study", Journal of Business Research, Vol. 83, pp. 30-37.

Tung, V.W.S., Chen, P.-J. and Schuckert, M. (2017), "Managing customer citizenship behaviour: the moderating roles of employee responsiveness and organizational reassurance", Tourism Management, Vol. 59, pp. 23-35.

UNWTO (2012), "Global report on food tourism", available at: http://cf.cdn.unwto.org/sites/all/files/ docpdf/amreports4-foodtourism.pdf (accessed 5 May 2017). 
UNWTO (2017), "Second global report on gastronomy Tourism - Affiliate members report: volume sixteen", available at: http://cf.cdn.unwto.org/sites/all/files/pdf/gastronomy_report_web.pdf (accessed 5 May 2017)

Upadhya, A. and Vij, M. (2016), "Creative tourist experience: role of destination management organizations", in Királová, A. (Ed.), Driving Tourism through Creative Destinations and Activities, IGI Global, Czech Republic, pp. 278-298.

Veal, A.J. (2006), "Research methods for leisure and tourism", A Practical Guide, 3rd ed., Pearson Education Limited, Essex.

Verma, V. and Chandra, B. (2018), "Sustainability and customers "hotel choice behaviour: a choicebased conjoint analysis approach", Environment, Development and Sustainability, Vol. 20 No. 3, pp. 1347-1363.

Williams, H.A., Yuan, J.J. and Williams Jr, R.L. (2019), "Attributes of memorable gastro-tourists' experiences”, Journal of Hospitality \& Tourism Research, Vol. 43 No. 3, pp. 327-348.

Wilson, E. and Hollinshead, K. (2015), "Qualitative tourism research: opportunities in the emergent soft sciences", Annals of Tourism Research, Vol. 54, pp. 30-47.

Zatori, A. and Beardsley, M. (2017), "On-site and memorable tourist experiences: trending toward value and quality-of-life outcomes", Advances in Hospitality and Leisure, Vol. 13, pp. 17-45.

\section{Corresponding author}

Susana Andreia Salgueiro Rachão can be contacted at: susanarachao@ua.pt

For instructions on how to order reprints of this article, please visit our website: www.emeraldgrouppublishing.com/licensing/reprints.htm

Or contact us for further details: permissions@emeraldinsight.com 